\title{
A Xenorbabdus budapestensis entomopatogén baktérium sejtmentes fermentlevének és tisztítottfehérje-frakciójának antimikrobiális hatása néhány zoonoticus baktériumra
}

\author{
Burgettiné dr. Böszörményi Erzsébet ${ }^{1}$ - Barcs István dr. ${ }^{1}$ \\ Domján Gyula dr. ${ }^{1}$ - Bélafiné dr. Bakó Katalin ${ }^{2}$. Fodor András dr. ${ }^{3}$ \\ Makrai László dr. ${ }^{4}$. Vozik Dávid ${ }^{2}$ \\ ${ }^{1}$ Semmelweis Egyetem, Egészségtudományi Kar, Epidemiológia Tanszék, Budapest \\ ${ }^{2}$ Pannon Egyetem, Mérnöki Kar, Veszprém \\ ${ }^{3}$ Department of Bacteriology, University of Wisconsin, Madison, USA \\ ${ }^{4}$ Szent István Egyetem, Állatorvos-tudományi Kar, Járványtani Mikrobiológiai Tanszék, Budapest
}

\begin{abstract}
Bevezetés: A folyamatosan megjelenó multirezisztens kórokozók és a bevetett új antibiotikumok között állandó „harc” folyik. A klinikumban és az állatgyógyászatban használt antibiotikumok jelentős része már nem hatékony. Eltérő hatásmechanizmusú antibakteriális peptidek alkalmazása alternatív megoldást jelenthet. A rovarpatogén Xenorbabdus budapestensis baktérium szintetizálni képes különböző antimikrobiális hatású fehérjekomponenseket (bicornutin-A, fabclavin). Célkitüzés: Xenorbabdus budapestensis antibakteriális hatásának mérése zoonózist okozó baktériumokon in vitro. Módszer: Gram-pozitív (Rhodococcus equi, Erysipelotbrix rhusiopathia, Staphylococcus aureus, Streptococcus equi, Corynebacterium pseudotuberculosis, Listeria monocytagenes) és Gram-negatív (Salmonella gallinarum, Salmonella derbi, Bordatella bronchoseptica, Escherichia coli, Pasteurella multocida, Aeromonas hydrophila) tesztbaktériumokon sejtmentes fermentlé és a tisztítottfehérje-biopreparátum antibakteriális hatásának mérése agardiffúzióval véres agaron. Eredmények: A Xenorbabdus budapestensis fehérjéket termel, amelyek hígításaitól függóen erős antibakteriális aktivitást fejtettek ki a tesztelt baktériumokon. A tisztított frakció hatása erősebb volt, mint a sejtmentes fermentlé. A Gram-pozitív baktériumok érzékenvebbek voltak. Következtetések: A Xenorbabdus budapestensis antimikrobiális hatású fehérjéi hatékonyságot mutattak a zoonózist okozó baktériumokon, és potenciális esélyük lehet e szervezetek elleni bevetésre, illetve azok megelózésében a jövőben. Orv. Hetil., 2015, 156(44), 1782-1786.
\end{abstract}

Kulcsszavak: Xenorhabdus budapestensis, fabclavin, bicornutin-A, zoonózis, antimikrobiális hatás

\section{Xenorbabdus budapestensis entomopathogenic bacteria cell free conditioned medium and purified peptide fraction effect on some zoonotic bacteria}

\footnotetext{
Introduction: Many multi-resistant patogens appear continuously resulting in a permanent need for the development of novel antibiotics. A large number of antibiotics introduced in clinical and veterinary practices are not effective. Antibacterial peptides with unusual mode of action may represent a promising option against multi-resistant pathogens. The entomopathogenic Xenorbabdus budapestensis bacteria produce several different antimicrobial peptides compounds such as bicornutin-A and fabclavin. Aim: The aim of the authors was to evaluate the in vitro antibacterial effect of Xenorhabdus budapestensis using zoonotic patogen bacteria. Method: Cell-free conditioned media and purified peptide fractions of Xenorhabdus budapestensis were tested on Gram-positive (Rhodococcus equi, Erysipelothrix rhusiopathia, Staphylococcus aureus, Streptococcus equi, Corynebacterium pseudotuberculosis, Listeria monocytage-
} 
nes) and Gram-negative bacteria (Salmonella gallinarum, Salmonella derbi, Bordatella bronchoseptica, Escherichia coli, Pasteurella multocida, Aeromonas hydrophila) using agar diffusion test on blood agar plates. Results: It was found that Xenorhabdus budapestensis bacteria produced compounds with strong and dose-dependent effects on the tested organisms. Purified peptid fraction exerted a more marked effect than cell free conditioned media. Gram-positive bacteria were more sensitive to this antibacterial effect than Gram-negative bacteria. Conclusions: Antibacterial peptide compound from Xenorhabdus budapestensis exert marked antibacterial effect on zoonotic patogen bacteria and they should be further evaluated in future for their potential use in the control or prevention of zoonoses.

Keywords: Xenorhabdus budapestensis, fabclavin, bicornutin-A, zoonosis, antimicrobial activity

Böszörményi, E., Barcs, I., Domján, Gy., Bakó, K., Fodor, A., Makrai, L., Vozik, D. [Xenorhabdus budapestensis entomopathogenic bacteria cell free conditioned medium and purified peptide fraction effect on some zoonotic bacteria]. Orv. Hetil., 2015, 156(44), 1782-1786.

(Beérkezett: 2015. július 30.; elfogadva: 2015. szeptember 2.)

\section{Rövidítések}

CFCM = sejtmentes fermentlé; HCL = hidrogén-klorid; LB = Luria-Broth tápleves folyadék; MBK = Mezőgazdasági Biotechnológiai Kutatóközpont; $\mathrm{MeOH}=$ metil-alkohol; $\mathrm{MIC}=$ minimális inhibitorkoncentráció; $\mathrm{NH}_{4} \mathrm{OH}=$ ammónium-hidroxid; $\mathrm{OD}=$ optikai denzitás; $\mathrm{OEK}=$ Országos Epidemiológiai Központ; $\mathrm{PF}=$ tisztítottbiopreparátum-frakció; $\mathrm{pH}=$ pondus Hidrogenii, hidrogénion-kitevó; SZIE = Szent István Egyetem; XAMP = Xenorhabdus antimikrobiális hatású peptid

Az antimikrobiális peptidek iránti kereslet magyarázata a sokféle klinikai igény, többek között első helyen áll az új, egyre nagyobb gyakorisággal megjelenő poli- és multirezisztens baktériumok okozta kihívás. A Xenorhabdus budapestensis rovarpatogén nematodák bélcsövében élő Gram-negatív baktérium, amelynek anyagcseretermékei között antimikrobiális aktivitású peptidek találhatóak [1], s bicornutin-A néven került leírásra. 2014-ben publikálták [2], hogy ez a fehérje nemcsak egy hexapeptidből áll, hanem egy egész hibridmolekulafehérje-család, amely a fabclavin elnevezést kapta. Bioszintéziséért egy géncluster felelős, amelyet molekuláris és bioinformatikai elemzéssel sikerült azonosítani.

$\mathrm{Az}$ antimikrobiális hatással rendelkező fehérje egyaránt hatékony volt előzetes kísérleteinkben növényi patogénen (Erwinia amylovora [1]), valamint állat-egészségügyi szempontból jelentős a tehenek mastitisét kiváltó baktériumokon (Staphylococcus aureus, Klebsiella pneumoniae) in vitro kísérletekben $[3,4]$.

E tesztelésre kiválasztott baktériumtörzsek azért számítanak különlegesnek, mert nagy részüket nem tesztelték az említett peptiddel szemben. A kísérleteket a Semmelweis Egyetem Egészségtudományi Karán múködő mikrobiológiai laboratóriumban végeztük. A tesztelésben szereplő sejtmentes fermentlé és a tisztított biopreparátum a Pannon Egyetem Vegyészmérnöki Karán müködő fermentációs laboratóriumban készült kooperációs munka keretében.

\section{Módszer}

A Xenorhabdus budapestensis DSM-16342 ${ }^{\mathrm{T}}$ EPB törzs XAMP-termelő primer variánsából készült el a sejtmentes fermentlé és a tisztított biopreparátum, amely a korábbi vizsgálatokban a legmagasabb antimikrobiális hatású anyag termelésére volt képes [5].

$\mathrm{Az}$ antimikrobiális hatású anyagot termelő baktériumot növesztettük LB-táplevesben, $25^{\circ} \mathrm{C}$ hőmérsékleten rázatva $(200 \mathrm{rpm})$ és 3 lépésben léptéket növelve. A stacioner fázis elérését követően centrifugáltuk a sejtkultúrákat $\left(15000 \mathrm{~g}, 20^{\circ} \mathrm{C}, 20\right.$ perc), majd $0,22 \mu \mathrm{m}$ pórusátmérőjü szúrővel (Merck Millipore) sejtmentesre szűrtük. Ebből készült a kísérletekhez a sejtmentes fermentlé. A sejtmentes kondicionált fermentléből (CFCM) 3 liter mennyiség további tisztításra került, és ebből készült el a tisztított peptidekben gazdag (PF) frakció, amelynek előkészítése a következő volt: Az előkészített oldatokat 48 órán keresztül rázattuk $150 \mathrm{rpm}$ fordulaton $20 \mathrm{~g} / 1-$ előzőleg desztillált vízben autokláv segítségével $\left(121^{\circ} \mathrm{C}\right.$, 30 perc) aktivált - Amberlite ${ }^{\circledR}$ XAD $1180^{\mathrm{R}}$ kationcserélő gyantával, a bioaktív anyagok adszorbeálása érdekében. A gyanta mosása és az extrahálás ez után több lépésben, különböző töménységü metanololdatokkal történt, a következő sorrendben: 11 steril desztillált víz, $500 \mathrm{ml}$ 25\%-os $\mathrm{MeOH}, 3 \times 300 \mathrm{ml} 50 \%$-os $\mathrm{MeOH}, 3 \times 300 \mathrm{ml}$ $80 \%$-os $\mathrm{MeOH}$, végül $300 \mathrm{ml} \mathrm{cc.} \mathrm{MeOH}$, amit $3 \mathrm{ml} 2 \mathrm{~N}$ HCl-dal savanyítottunk meg. A savas kémhatású, tömény metanolos frakciót - amely tartalmazza az antimikrobiális hatással rendelkező komponenseket - rotációs vákuumdesztilláció segítségével $\left(35^{\circ} \mathrm{C}\right)$ bepároltuk hozzávetőleg $50 \mathrm{ml}$ térfogatra, majd $2 \mathrm{~N} \mathrm{NH}_{4} \mathrm{OH}$-oldat segítségével közömbösítettük $\mathrm{pH}=6$ értékig. A neutralizált mintát ez után teljesen szárazra pároltuk, így nyertünk a folyamat végén $47,7 \mathrm{mg} / \mathrm{ml}$ száraz anyagtartalmú anyagot, amelyet $10 \mathrm{ml}$ desztillált vízben, hütőszekrényben tároltunk steril csőben felhasználásig.

Az elkészített CFCM és PF anyagnak (100\%, 80\%, $60 \%, 40 \%, 20 \%)$ különböző hígításaival végeztük a kísér- 


\begin{tabular}{|c|c|c|c|}
\hline Tesztelt baktériumok & Néhány sajátosság & $\begin{array}{l}\text { Antibiotikum-érzékenységi eredmények* } \\
\text { (R: rezisztens, 0-15 mm közötti a gátlási zóna átmérője) }\end{array}$ & Törzsek forrása \\
\hline Rhodococcus equi & $\mathrm{Gr}^{+}$coccus & AMC: R, AMX: R, CTX: R, IPM: R, QD: R, P: R, RA: R, S: R & Makrai L. (SZIE) \\
\hline Erysipelothrix rhusiopathia & $\mathrm{Gr}^{+}$coccus & AMC: R, AMX: R, CM: R, CTX: R, KM: R, RA: R, P: R & Makrai L. (SZIE) \\
\hline Staphylococcus aureus & $\mathrm{Gr}^{+}$coccus & B: R, CFM: R, CIP: R, IPM: R, OX: R, QD: R, S: R, VA: R & OEK törzsgyüjtemény \\
\hline Streptococcus equi & $\mathrm{Gr}^{+}$coccus & B: R, CFM: R, IPM: R, PB: R, S: R & Makrai L. (SZIE) \\
\hline $\begin{array}{l}\text { Corynebacterium } \\
\text { pseudotuberculosis }\end{array}$ & $\mathrm{Gr}^{+}$coccus & $\begin{array}{l}\text { AMX: R, CTX: R, FT: R, IPM: R, KM: R, RA: R, S: R, QD: R, } \\
\text { P: R, PB: R }\end{array}$ & OEK törzsgyưjteméy \\
\hline Listeria monocytagenes & $\mathrm{Gr}^{+} \mathrm{coccus}$ & CFM: R, CTX: R, CIP: R, FT: R, KM: R, S: R, P: R, PB: R & Makrai L. (SZIE) \\
\hline Salmonella gallinarum & $\mathrm{Gr}^{-}$pálca & $\begin{array}{l}\text { AMC: R, AMX: R, CIP: R, CLR: R, CS: R, GM: R, IPM: R, } \\
\text { MUP: R }\end{array}$ & OEK törzsgyưjteméy \\
\hline Salmonella derbi & $\mathrm{Gr}^{-}$pálca & AMC: R, AMX: R, CIP: R, CS: R, IPM: R, QD: R, P: R, RA: R & OEK törzsgyűjteméy \\
\hline Bordatella bronchoseptica & $\mathrm{Gr}^{-}$pálca & CLR: R, CTX: R, CFM:R, FT: R, IPM: R, QD: R, P: R, S: R & Makrai L. (SZIE) \\
\hline Escherichia coli OF280 & $\mathrm{Gr}^{-}$pálca & AMX: R, CM: R, E: R, KM: R, P: R, RA: R & $\begin{array}{l}\text { Olasz F. (MBK) } \\
\text { humán izolátum }\end{array}$ \\
\hline Pasteurella multocida & Gr- pálca & AMX: R, P: R & Makrai L. (SZIE) \\
\hline Aeromonas hydrophila & $\mathrm{Gr}^{-}$pálca & AMC: R, DO: R, E: R, FT: R, MTR: R, P: R, TE: R & Makrai L. (SZIE) \\
\hline
\end{tabular}

*Antibiotikum-korongok rövidítése a gyártó által megjelöltek szerint: $\mathrm{AMC}=$ amoxicillin+clavulánsav, $\mathrm{AMX}=\mathrm{amoxicillin}, \mathrm{B}=\mathrm{bacitracin}, \mathrm{CFM}=$ cefixim, CIP = ciprofloxacin, CLR = clarithromycin, $\mathrm{CM}=$ clindamycin, $\mathrm{CTX}=$ cefotaxim, $\mathrm{CS}=$ colistin, $\mathrm{DO}=\mathrm{doxycyclin}, \mathrm{E}=\mathrm{erythromycin}$, $\mathrm{FT}=$ nitrofurantoin, $\mathrm{GM}=$ gentamycin, $\mathrm{IPM}=$ imipenem, $\mathrm{KM}=$ kanamycin, $\mathrm{MTR}=$ metronidazol, $\mathrm{MUP}=\operatorname{mupirocin}, \mathrm{OX}=\mathrm{oxacillin}, \mathrm{P}=$ penicillin, $\mathrm{PB}=$ polymixin, $\mathrm{QD}=$ quinupristin-dalfopristin, $\mathrm{RA}=$ rifampicin, $\mathrm{S}=$ streptomycin, $\mathrm{TE}=$ tetracyclin, $\mathrm{VA}=\mathrm{vancomycin}$.

leteinket véres agar lemezeken, agardiffúziós technikával, aerob körülmények között, mindhárom párhuzamos alkalmazásával [6]. A tisztított frakciók és hígításai az alábbi szárazanyag-koncentrációkat tartalmazták: 100\% $(0,47), 80 \%(0,38), 60 \%(0,28), 40 \%(0,19), 20 \%(0,095$ $\mu \mathrm{g} / \mathrm{ml})$. Az OD-t minden egyes baktériumnál 0,5-re állítottuk be $0,5 \mathrm{McF}$ arland-standarddal.

A patogén baktériumból $300 \mu$ l-t elözetesen $54{ }^{\circ} \mathrm{C}$ hőmérsékletű, 2,7 ml térfogatú lágy agarban szuszpendáltunk, majd egy hirtelen mozdulattal ráöntöttük a véres agar lemezre. 20' várakozás után a lágy agar megdermedt, és ezekbe készítettük steril lyukfúróval a $9 \mathrm{~mm}$ átmérőjü furatokat. A furatokba $100 \mu \mathrm{l}$ CFCM és PF különböző hígításai kerültek. Beoltás után az agardiffúzós lemezeket $37^{\circ} \mathrm{C}$-os termosztátba helyeztük és a következő 48 órán belül sor került a gátlási zónák átmérőinek a mérésére. A mérőoldatokat és a hígítások elkészítését a Clinical and Laboratory Standards Institute által közölt makrohígításos módszerben leírtaknak megfelelően végeztük. A tesztelt baktériumok antibiotikum-érzékenységét papírdiffúziós korongtechnikával készítettük el a nemzetközi ajánlások betartása mellett Müller-Hinton-agarlemezeken [7]. A tesztelt baktériumok rezisztenciaeredményeit láthatjuk néhány vizsgált antibiotikummal szemben az 1. táblázatban.

\section{Eredmények}

A Xenorhabdus budapestensis baktériumból készített sejtmentes fermentlé és a tisztított biopreparátum antimikrobiális hatást fejtett ki valamennyi, tesztelésben részt vevő baktériumra agardiffúziós kísérleteinkben. A gátlási zónákat 48 órán belül mértük a véres agar lemezeken. A gátlási zónák nagysága a kezelést követő napon már kialakult és azok mérete nem változott. A peptid antimikrobiális hatását ezért „baktericidnek” feltételezzük. A furat körüli feltisztulást mm-ben mértük és hasonlítottuk össze a két kezelt anyagnál. A biopreparátum esetében 3-4 mm-nél nagyobb gátlási zónák alakultak ki átlagosan, így eróteljesebb antimikrobiális hatást fejtett ki ugyanazon hígításoknál (1. ábra), mint a sejtmentes fermentlé (2. ábra). Eredményeinkból látható, hogy a hígítások nagysága jelentős mértékben befolyásolta a gátlási zóna nagyságát.

A Gram-pozitív baktériumok érzékenyebbek voltak, mint a Gram-negatív baktériumok, függetlenül attól, hogy azok milyen antibiotikum-érzékenységgel rendelkeztek. Vizsgálatainkban a legnagyobb érzékenységet a Gram-pozitív Rhodococcus equi, a legkisebb érzékenységet a Gram-negatív Aeromonas hydrophila érte el.

\section{Megbeszélés}

A Xenorbabdus budapestensis baktériumok sejtmentes fermentlevében (CFCM) és annak tisztított biopreparátumában (PF) antimikrobiális hatású (fabclavin, bicornutin-A) fehérjék találhatóak. Összehasonlítottuk 12, zoonózist okozó baktérium érzékenységét ezen fehérjékkel szemben. A tesztelt baktériumok jelentős része állat-egészségügyi járványokból származó izolált és azonosított baktériumtörzs volt. 


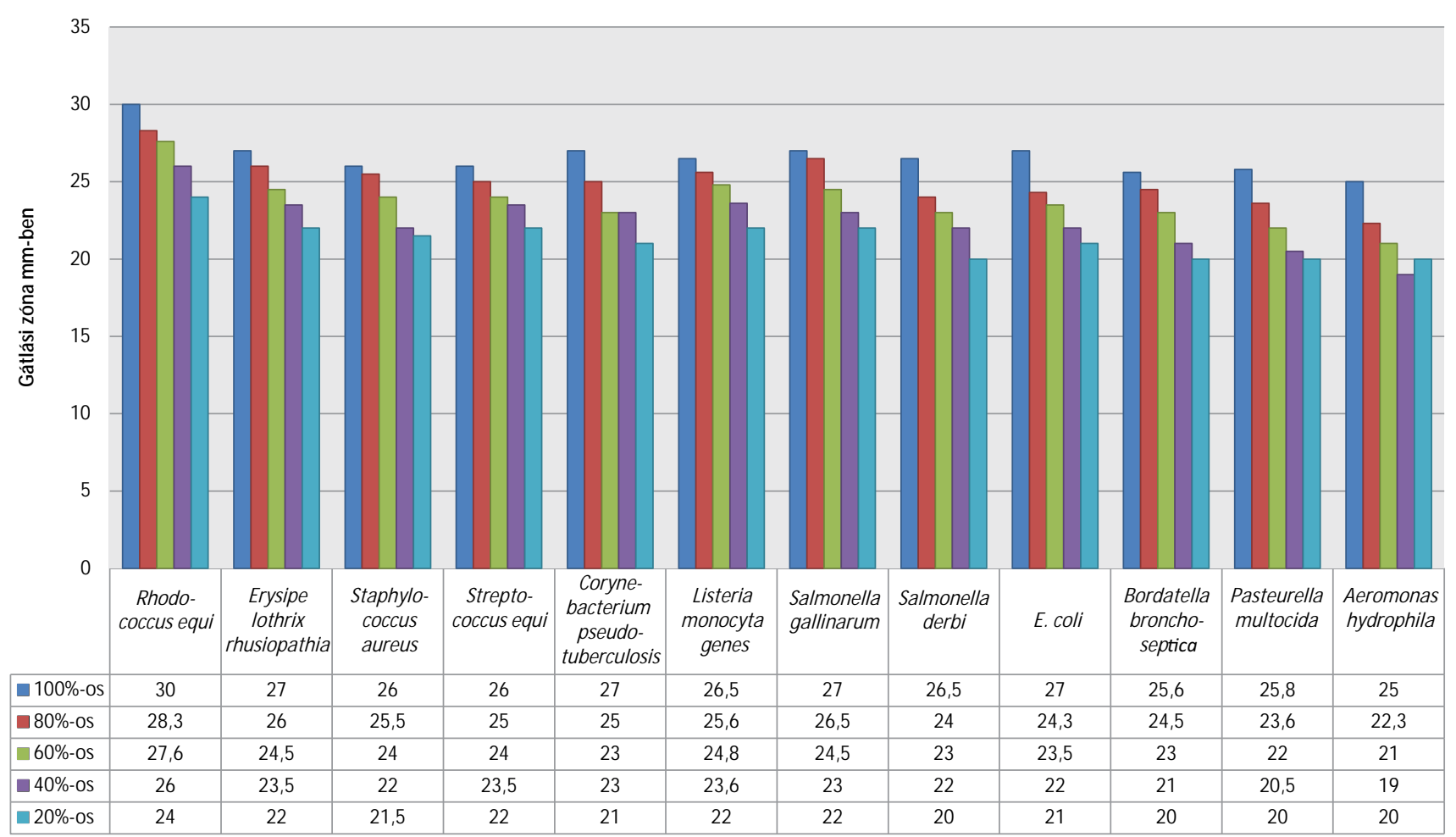

1. ábra |A Xenorbabdus budapestensis PF tisztított fehérjékben gazdag frakciójának antimikrobiális hatása a tesztelt baktériumokon

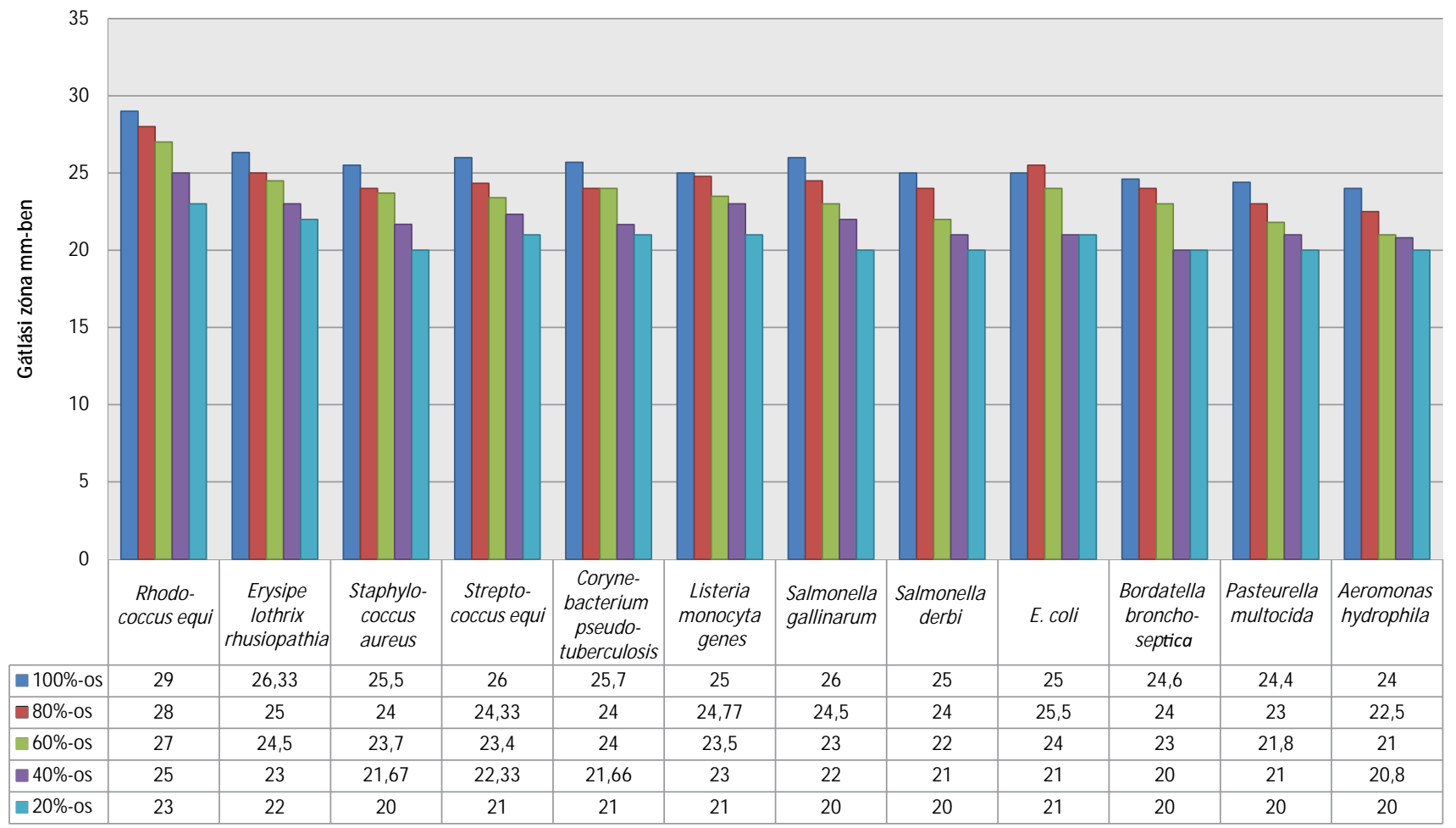

2. ábra $\mid$ Xenorbabdus budapestensis CFCM sejtmentes frakciójának antimikrobiális hatása a tesztelt baktériumokon

Előzetesen felmértük a baktériumtörzsek antibiotikum-érzékenységét. Összefüggést nem találtunk a XAMP-érzékenység és a különféle antibiotikumokkal szembeni rezisztencia között. Valamennyi vizsgált bakté- rium érzékenységet mutatott. A tesztelt (CFCM, PF) anyagok $20 \%$-os hígításai elérték a baktérium szaporodásának gátlásához szükséges MID-értéket. Eredményeink alapján látható, hogy a PF hatása erősebb volt a külön- 


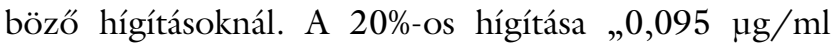
hatóanyag-tartalom" mellett elérte a baktériumok szaporodásának gátlásához szükséges hatást, amelyet „baktericid”-nek feltételezünk.

\section{Következtetések}

Eredményeink megerősítik azt, hogy XAMP nemcsak a növényorvoslás [8] hasznos eszköze lehet, hanem arra is jó esély van, hogy az állatgyógyászatban és talán a humán klinikumban is a jövő antibiotikumává váljon, a szükséges vizsgálatokat követően [9]. Feltételezzük, hogy a peptid a sejtmembránt károsítja, „kilyukasztja” azt, így az a baktérium pusztulásához vezet. Eredményeink alapján a hibrid fehérje széles hatásspektrumú, amellyel szemben gyors rezisztenciakialakulás nem várható.

$\mathrm{Az}$ általunk felfedezett és korábban leírt bicornutin- $A$ potenciális esélyeire utal, hogy a Helix BioMedix gyár az elmúlt 20 évben foglalkozik antimikrobiális hatással rendelkező peptidek kutatásával. Többek között hexapeptidsorokat állít elő, amelyet sikerült szabadalmaztatni abból a célból, hogy bakteriális és gombapatogének ellen alkalmazzák [10].

Anyagi támogatás: A közlemény megírása anyagi támogatásban nem részesült.

Szerzôi munkamegosztás: A szerzők a kézirat megírásában egyenlő arányban vettek részt. A cikk végleges változatát valamennyi szerző elolvasta és jóváhagyta.

Érdekeltségek: A szerzőknek nincsenek érdekeltségeik.

\section{Irodalom}

[1] Böszörményi, E., Érsek, T., Fodor, A., et al.: Isolation and activity of Xenorbabdus antimicrobial compounds against the plant pathogens Erwinia amylovora and Phytophthora nicotianae. J. Appl. Microbiol., 2009, 107(3), 746-759.
[2] Fuchs, S. W., Grundmann, F., Kurz, M., et al.: Fabclavines: bioac tive peptide-polyketide-polyamino hybrids from Xenorbabdus. ChemBioChem., 2014, 15(4), 512-516.

[3] Furgani, G., Böszörményi, E., Fodor, A., et al.: Xenorbabdus antibiotics: a comparative analysis and potential utility for controlling mastitis caused by bacteria. J. Appl. Microbiol., 2008, 104(3), 745-758.

[4] Fodor, A., Hevesi, M., Mathe-Fodor, A., et al.: Novel anti-microbiol peptides of Xenorhabdus origin against multidrug resistant plant pathogens. In: Bobbarala, V. (ed.): Biochemistry, Genetics and Molecular Biology - A Search for Antibacterial Agents. InTech Academic Publisher, Rijeka, 2012, 148-196.

[5] Lengyel, K., Lang, E., Fodor, A., et al.: Description of four novel species of Xenorbabdus, family Enterobacteriaceae: Xenorbabdus budapestensis sp. nov., Xenorhabdus eblersii sp. nov., Xenorbabdus innexi sp. nov., and Xenorbabdus szentirmaii sp. nov. Syst. Appl. Microbiol., 2005, 28(2), 115-122.

[6] Bonev, B., Hooper, J., Parisot, J.: Principles of assessing bacterial susceptibility to antibiotics using the agar diffusion method. J. Antimicrob. Chemother., 2008, 61(6), 1295-1301.

[7] CLSI 2012. Methods for Dilution Antimicrobial Susceptibility Tests for Bacteria That Grow Aerobically; Approved Standard Nineth Edition. CLSI document M07-A9. Clinical and Laboratory Standards Institute, Wayne, 2012.

[8] Vozik, D., Böszörményi, E., Fodor, A., et al.: Xenorhabdus budapestensis entomopatogen bacteria purified fraction effect fire bligh against. [Xenorbabdus budapestensis entomopatogén baktérium sejtkultúrájából nyert tisztított frakció hatásossága tûzelhalás ellen.] Georgikon Agricultur. AMJ Agricult. Sci., 2015, 19, 46-51. [Hungarian]

[9] Böszörményi, E., Fodor, A., Hogan, J., et al.: Multi-drug resistant Gram-negativ pathogens against protection by Xenorhabdus antimicrobial peptid used in vitro. [Multi-drog rezisztens Gramnegatív patogének elleni védekezés lehetôsége Xenorhabdus antimikrobiális peptidek felhasználásával: in vitro kísérletek eredményei.] Georgikon Agricultur. AMJ Agricult. Sci., 2014, 19, 84-90. [Hungarian]

[10] Falla, T. J., Zhang, L., Harris, S. M.: Antimicrobial hexapeptides. US Patent, 2008, 407(7), 940.

(Burgettiné dr. Böszörményi Erzsébet, e-mail: boszormenyie@se-etk.hu) 